\title{
Is there under-provision of training?
}

\author{
Giorgio Brunello ${ }^{a}$, Maria De Paola ${ }^{b, *}$ \\ ${ }^{a}$ University of Padova, IZA and CESifo \\ ${ }^{b}$ University of Calabria
}

\begin{abstract}
This paper reviews both the theoretical underpinnings and the empirical evidence in support of the under-provision of general training. In spite of many theoretical reasons for the realization of inefficient levels of training, it is difficult to find convincing empirical evidence. Taking as a starting point the large empirical literature showing that employers provide and pay for general training, we argue that, if firms invest in general training, important evidence on underprovision can be obtained by looking at the relationship between investment in training and turnover. Using the 7 waves (1995-2001) of the European Community Household Panel (ECHP) for 12 European countries, we find a negative but not statistically significant relationship between training and turnover. We conclude that, at the current state of the knowledge, it is difficult to justify training policies widespread in many European countries using efficiency arguments.
\end{abstract}

Keywords: training, efficiency, turnover

\section{Introduction}

Human capital, accumulated at school or in the labor market, is a key determinant of wages and employment opportunities (Lynch, 1992; Bishop, 1997; Arulampalam and Booth, 2001; OECD, 1999; Dearden et al., 2006; Ok and Tergeist, 2003) and an important factor affecting economic growth (De la Fuente and Ciccone, 2002; OECD, 2001). Skill upgrading and the avoidance of skill obsolescence are relevant features of policies designed to increase labor market participation and the length of the working life and to reduce the social exclusion of particular groups and the consequences of population ageing.

Since many professional activities require skills that can only be acquired by direct experience, substantial investment in human capital takes place on-the-job rather than at schools or in specialized institutions. In this paper we focus on general training provided by firms. Many empirical studies show that there is substantial variation across countries and across socio-economic groups in training participation rates, with Nordic countries showing higher participation than Southern European countries (Ok and Tergeist, 2003) and low-educated and older workers generally

\footnotetext{
${ }^{*}$ Corresponding author: Dipartimento di Economia e Statistica, University of Calabria, P. Bucci, Arcavacata di Rende, Cosenza. E-mail: m.depaola@unical.it
} 
participating less than other groups in training activities. Are these differences due to inefficiencies? More generally, do enterprises and workers invest enough in training?

Under - provision can only be defined with respect to a benchmark. The natural benchmark is the efficient level of training, which maximizes total output net of training costs. Equality of (private and social) marginal benefits and marginal costs does not imply that the efficient level of training is the same across different groups of individuals or countries. For instance, the poorly educated may face higher training costs because education and training are complements. Given marginal benefits, this group should receive less training. Therefore, the observation that the poorly educated receive less training than the better educated is not by itself evidence of inefficient under-provision. Of course, the level of training of individuals with lower educational attainment might be depressed below the first best level by other factors, such as higher turnover rates, which reduce investments in general training, and more binding liquidity constraints. Similarly, some countries might invest too little in training because of labor market institutions or imperfect capital markets. In these situations we might have a case for under-investments, since they are characterized by aspects that, according to human capital theory, may hinder individuals from investing efficiently.

Even if Becker's work $(1962,1964)$ on human capital investments has strongly influenced all the subsequent literature, some important differences emerge in relation to the hypothesis adopted on labour market competition. Becker, assuming perfectly competitive labour markets, extends the efficiency result (guaranteed by the working of free market forces) also to this type of investment. Some exceptions come into view when individuals are liquidity constrained (problems related to the capital market) or when there are legal constraints, such as minimum wages, which do not allow workers to accept a sufficiently low initial wage. Conversely, inefficient results are typical of those analysis considering imperfectly competitive labour markets. In this kind of labour markets the investing subject is not able to obtain the full return on his investment and consequently social returns do not coincide with private ones. Moreover, when the investing subject is the firm, training returns are reduced by turnover, which generate a positive externality to other firms.

Although there are many theoretical reasons for under-investment, it is difficult to find direct empirical evidence on this phenomenon, mainly because training costs and returns - on which efficiency evaluations are based - are hardly ever measured. In spite of the scant empirical evidence on training under-investment, training policies aimed at increasing investments realized both by firms and workers are widespread in many OECD countries. Schemes directed to firms usually consist in levy schemes which require firms to pay a tax and obtain resources to award grants to support training (levy-grant schemes, diffused in Belgium, Spain and Italy), or which impose on firms to pay a tax if they do not meet a pre-determined level of training (train-or-pay schemes adopted in France and in the province of Quebec, Canada). In other cases, for example in Austria (in 2000), Italy (in 2001) and Luxembourg (in 1999), firms are allowed to deduct some or all training costs and thereby to reduce corporate taxes 
(see OECD 2003a). Quite diffuse are also schemes directed to individuals. Loans financing adult learning have been introduced in US and UK, while an increasing number of countries are experimenting different types of subsides. Training vouchers are used in certain regions of Austria, Italy and Switzerland, while individual learning accounts, consisting in saving accounts that can be opened by individuals to fund training activities, with contribution from third parties (government and employer), are experimented in Canada, the Netherlands, the Basque region of Spain, the United Kingdom and the United States (for a review see OECD 2003b).

In discussing the empirical evidence on training under-investment we will show that there is not a strong efficiency argument on which these policies can be based. In addition, while evaluations of training interventions and other active labour market policies directed to unemployment are becoming frequent also in European countries, costs and benefits of training policies directed to firms and employed workers are mainly unknown, since rigorous evaluations are missing.

In this paper we investigate the under-investment issue by looking at the relationship between training and turnover. If training increases turnover and labor markets are imperfectly competitive the private marginal benefit to the current firmworker pair is unambiguously below the social one. This is non necessarily the case if training reduces turnover, since this effect may compensate other sources of underprovision and close or even eliminate the gap between efficient and actual training outcomes. We investigate this issue using the 7 waves (1995-2001) of the European Community Household Panel (ECHP) for 12 European countries. However, we do not find any conclusive evidence, since the estimated relationship between employer - provided training and subsequent turnover is negative but not statistically significant. We conclude that even if the risk of poaching may actually represent a factor preventing the realization of an efficient level of investment in training, the empirical evidence at hand is not sufficiently informative to support training policies. Much more should be known before designing effective policies.

The paper is organized as follows. The second section presents a theoretical model which highlights the different causes of under-provision. Section three discusses the available empirical evidence. In section four, using data from ECHP, we investigate the relationship between training and separation rates. Section five offers some concluding remarks.

\section{The under-provision of training: theory}

In this section we present a theoretical framework to discuss the investment in general training both in the case of perfectly competitive labor markets and in the case of labor market imperfections. The aim is that of illustrating different causes of training under-investment - by restricting attention to general training. There is a broad agreement that under-investment problems are especially relevant for this type of training, since externalities generating under-investment become less relevant when training is more specific. 
Assume that firms are identical and that individuals live and work for two periods. Training takes place during the first period, when both productivity and wages are equal to zero, and is completely general. Productivity and wages in the second period are denoted respectively by $y$ and $w$. In addition, we assume that in the second period there is an instantaneous probability of separation denoted by $q$. For the sake of simplicity, we assume a discount factor equal to one. Optimality requires choosing an amount of training such as any further increase in training would imply a marginal increase in output smaller than the corresponding marginal increase in costs:

$$
y^{\prime}(s)=c^{\prime}(s)
$$

In a perfectly competitive labour market, the worker obtains a wage equal to the marginal product. Since the investment in general human capital increases the recipient's productivity in all firms operating in the market, the firm currently employing the worker will not be prepared to finance this kind of investment. As shown by Becker (1962) because workers fully capture the benefits of training via higher wages, they will finance the investment in general skills and pay for it either directly or by accepting lower wages during the training period ${ }^{1}$. The level of investment realized by the worker will be efficient, in fact training will produce a wage increase equal to the increase in productivity, and the worker's choice will satisfy the following condition:

$$
w^{\prime}(s)=y^{\prime}(s)=c^{\prime}(s)
$$

In this framework there is under-provision of training if liquidity or legal constraints, such as minimum wages, do not allow workers to accept a sufficiently low initial wage. Under-provision also emerges when individuals are not fully rational or perfectly informed. These problems might be more relevant for certain groups of workers than for others. For example, low-income workers might be particularly affected by credit constraints, or might be unable to collect information about training returns.

Additional problems emerge if returns to training are uncertain, either because of shocks to the demand of particular competencies or because of uncertainty about

\footnotetext{
${ }^{1}$ In the beckerian framework the distinction between firm specific and general human capital plays a crucial role in defining who bears the investment cost. When training is firm specific, the costs and revenues are shared by the worker and the firm. This result is based on the fact that the investment is lost if the worker and the firm separate after training. In contrast with the case of general training in a perfectly competitive labor market, this creates a wedge between worker's productivity - which increases with training- and outside option - which does not. To avoid quits the firm is willing to pay the trained worker a wage higher than her outside option. However, the optimal wage (from the point of view of the firm) will be somewhere between the worker's productivity and her outside option; therefore, the optimal contract implies that costs are shared as well. Hashimoto (1981), considering the case of asymmetric information, formally shows that the shares of cost paid by the firm and the worker depend on the relationship between quit rates and wages, layoff rates and profits, and on other variables such as the cost of funds and the attitude toward risk of the parties involved. He also shows that the level of training investment is ex-ante efficient, even in the presence of ex-post inefficient turnover.
} 
the ability to acquire a certain qualification or skill level. Since workers are unlikely to obtain insurance against these types of risk they may be discouraged to invest in training (Layard, Robinson and Steedman, 1995).

Clearly the efficient level of training emerging from Becker analysis holds only if the firm can credibly commit to the investment level the worker is paying for. Difficulties in measuring and verifying training quantity and quality pose very relevant problems of opportunism, which have been considered both in relation to specific investments (Williamson, 1975; Hashimoto, 1981; Prendergast, 1993; Kahn and Huberman, 1988; MacLeod and Malcomson, 1993) and in relation to investments in general human capital financed by workers (Acemoglu and Pischke, 1999a; Malcomson, Maw and McCormick, 2002). In addition, these problems may aggravate the conflicting interests of employers and employees concerning the type of skills (general or specific) to be provided (Stevens, 1994) ${ }^{2}$. Workers might be discouraged to invest in human capital since they are skeptical about the skills provided by the firm being sufficiently general to ensure a high productivity and wages in other firms.

As recently stressed by a number of papers (Stevens, 1994; Acemoglu and Pischke, 1998, 1999a,b), new sources of inefficiency emerge with imperfectly competitive labor markets. In this environment, firms may be willing to bear some or all the costs of providing general training if the increase of productivity induced by training is higher than the wage increase, that is, if there is wage compression ${ }^{3}$. The divergence between productivity and wages might arise for several reasons, including mobility costs, search and matching frictions, the complementarity between general and specific skills, and asymmetric information. As reviewed by Leuven (2005) we can distinguish between two cases of information asymmetries: first, the training firm is better informed than the market about the skills acquired by its employees; second, the training firm is better informed about the abilities of its workers, which gives rise to adverse selection. All these imperfections reduce the outside option of workers investing in training. As shown by Acemoglu and Pischke (1998, 1999a, 1999b, 2003) they turn general skills into de facto specific skills.

To illustrate, let us consider the above analytical framework and for the sake of simplicity let us assume that the firm is the only investing subject. Privately optimal training investment $s$ is decided by each firm in the market to maximize the following profit function, where $q$ is the exogenous instantaneous probability of separation:

$$
(1-q)[y(s)-w(s)]-c(s)
$$

Therefore profit maximization implies choosing a level of training such as the

\footnotetext{
${ }^{2}$ Enforcement problems and imperfections in the training market often go together with imperfectly competitive labor market. In fact, if training is difficult to verify for subjects external to the employment relationship, the worker's outside option will be below his productivity. It is, however, possible to have perfectly competitive labour markets but workers who do not trust the firm in providing the promised level of training and as a consequence do not undertake efficient investments.

${ }^{3}$ Booth and Zoega (2004) clarify the distinction between absolute and relative wage compression and show that only absolute wage compression constitutes a necessary condition for firms to invest in general training.
} 
marginal increase in returns, which occur only with probability $(1-q)$, is equal to the marginal increase in costs:

$$
(1-q)\left[y^{\prime}(s)-w^{\prime}(s)\right]=c^{\prime}(s)
$$

where the primes are for first derivatives. The firm will invest in training if the post-training productivity increases in training intensity at a faster rate compared to the wage. The comparison of (1) and (4) shows that each firm in this market underinvests in training if $w^{\prime}(s)>0$ - that is if wages increase with training - because it cannot reap all the returns to the training investment. Moreover, training is negatively affected by the probability of quitting $q>0$ and by poaching, which occurs when the productivity after training at the new firm is higher than the outside option.

From (4) it is possible to see that employer provided training increases with the monopsonistic power of the firm. It is relevant to notice that the firm's monopsonistic power might differ across different types of workers ${ }^{4}$. For example, some workers might be more affected by adverse selection problems or, due to the type of tasks they manage, might have a more firm-specific human capital. Besides, according to this approach wage compression might be induced also by institutional features, such as minimum wages and union wage bargaining, which lead to theoretical predictions that are in sharp contrast with those derived from Becker's analysis. The interest of firms in financing general skill acquisition by workers is greater when, as a result of monopsonistic power or institutional regulations, the wage structure is more distorted. For example, unionization can increase training by improving the commitment on wage contracts and reducing the hold up problem (Ryan, 1994; Booth, Francesconi and Zoega, 2003), or by playing a relevant role in reducing labor turnover (Blau and Kahn, 1983; Freeman and Medoff, 1984, Booth and Chatterji, 1998); or by reducing the dispersion of wages between trained and un-trained employees $^{5}$. As argued by Acemoglu and Pischke (1999) a positive effect on training may also derive from minimum wages. Since firms have to pay the minimum wage even to their unskilled workers, firms may find it convenient to invest in training to increase the productivity of less skilled workers. According to Fella (2005) a similar effect may emerge also from employment protection. In fact, since investment in general training increases the worker's productivity outside the training firm, the latter might be interested in investing in training to save firing costs in the case of

\footnotetext{
${ }^{4}$ As argued by De Paola and Scoppa (2003), better educated workers can also have highly dispersed abilities - because acquiring education not only improves skills but also makes them more variable which, in the case of adverse selection problems, translate into lower outside options and in a higher incentive for firms to invest in their human capital. Booth and Zoega (2000) show that firms' incentives to invest in general training are increasing in task complexity. Workers' heterogeneous observable innate ability affects the variety of tasks which can be performed within a firm and generates monopsony power to firms with a 'better' workforce. Since the degree of monopsony power is increasing in task complexity, firms with a workforce involved in more sophisticated tasks are more willing to finance general training.

${ }^{5} \mathrm{On}$ the other hand, unions may want to push for equality in the provision of training, with negative consequences on overall training investment, which goes beyond the training of the less advantaged groups. In addition, unions often oppose the introduction of new technologies requiring skill up-grading and by so doing indirectly oppose training.
} 
dismissals. The reason is that the firing cost is bargained between the parties, and is lower the higher the outside option available to the worker ${ }^{6}$.

To complete our analysis suppose now that both the firm and the worker invest in training and let the share of training costs born by the employee be $\sigma \in(0,1)$. Training is fully contractible. In case of separation let us suppose that the firm outside option is zero, while the worker's outside option is $v(s)$. Denoting with $\beta$ the worker's bargaining power, the wage resulting from Nash bargaining will be $w(s)=v(s)+\beta(y(s)-v(s))$. While the first best still require that (1) holds, the firm's choice is given by the condition:

$$
\left.(1-q)(1-\beta)\left[y^{\prime}(s)-v^{\prime}(s)\right]\right)=(1-\sigma) c^{\prime}(s)
$$

and the worker's choice satisfies

$$
v^{\prime}(s)+(1-q) \beta\left[y^{\prime}(s)-v^{\prime}(s)\right]=\sigma c^{\prime}(s)
$$

Since the total marginal returns of training of both the firm and the worker are equal to $(1-q) y^{\prime}(s)+q v^{\prime}(s)$, if parties can commit on training levels, the efficient solution can be reached only when this return is equal to $y^{\prime}(s)$, as in the following:

$$
(1-q) y^{\prime}(s)+q v^{\prime}(s)=y^{\prime}(s)
$$

which can be written as

$$
q v^{\prime}(s)=q y^{\prime}(s)
$$

which is verified either with $q=0$, or when $v^{\prime}(s)=y^{\prime}(s)$. In the latter case the employee bears all the costs and reaps all the returns to training. Therefore, $\sigma$ must be equal to 1 and we are back to Becker's case. On the contrary, when $v^{\prime}(s)<y^{\prime}(s)$ both the worker and the firm under-invest (see Acemoglu, 1997). In fact, the worker gets less than his marginal product in the future job, which generates under-investment. The investment realized by the firm is also inefficient, since turnover creates positive training externalities. If quit rates are positive and firms in the market pay less than productivity, outside firms earn a profit from training, which is not considered by training firms when deciding whether to invest ${ }^{7}$. This poaching externality reduces the incentive to train (see Stevens, 1996; Katz and Zidermann, 1990).

\footnotetext{
${ }^{6}$ Arulampalam and Booth (1998) investigate the nexus between work-related training and labor market "flexibility" and suggest that there is a trade-off between expanding marginal forms of employment and expanding the proportion of the workforce getting work-related training. Therefore, the emphasis on the need to increase flexibility in the labor market might not be compatible with the increase in the stock of work-related skills by workers.

${ }^{7}$ An alternative view has been offered by Booth and Zoega (1999) who have argued that when there is uncertainty about future productivity, a higher quit rate reduce the importance of future flows and the option value of waiting rather than training.
} 
An important aspect missing from the above analysis is that training can affect turnover. Letting $q^{\prime}(s)$ be the marginal change of turnover induced by training, condition (7) can be re-written as follows

$$
(1-q) y^{\prime}(s)+q v^{\prime}(s)-q^{\prime}(s) y(s)+q^{\prime}(s) v(s)=y^{\prime}(s)
$$

or

$$
-q^{\prime}(s)[y(s)-v(s)]=q\left[y^{\prime}(s)-v^{\prime}(s)\right]
$$

In this case, the first best solution cannot be excluded a priori when $q^{\prime}(s)$ is negative. If the firm is the only investing subject this condition becomes:

$$
-q^{\prime}(s)[y(s)-v(s)]=y^{\prime}(s)\left[\frac{q(1-\beta)+\beta}{1-\beta}\right]+(1-q) v^{\prime}(s)
$$

A first best solution may emerge in this case if training reduces turnover. For example, if firms cannot commit ex-ante to the wage they will pay to the trained worker and wages are set to maximize ex-post profits, a trade-off between high wages and low turnover rates emerges. In these circumstances, firms can use training as a commitment device to reduce turnover. Therefore, with ex-post wage determination, it is not possible to rule out training over-investment. This can be seen in equation (9) when $q^{\prime}(s)$ is allowed to be negative.

The prediction of the theoretical literature with respect to the influence of training on turnover rates is mixed. According to Jansen (1998), skills acquisition makes workers more apt to adjust to higher flexibility and reduces the probability of separations induced by negative shocks. Acemoglu and Pischke (1999) assume that training does not affect turnover. On the other hand, as argued by Black and Lynch (1998) "training itself may contribute to employee turnover: if new skills are of value to other employers then firms risk having their trained employee hired away".

In order to show that the effect of training on turnover can be either negative or positive, suppose that the worker's outside option is equal to $v(s)+\varepsilon$, where $v(s)$ is a deterministic variable and $\varepsilon$ is a stochastic variable uniformly distributed in the range $[-k(s),+k(s)]$ (with density function $f(\varepsilon)=1 / 2 k(s)$ ). This specification is based on the idea that not only the worker's outside option increases with training but also that shocks that hit his outside option are related to the training level. This could be because training increases the range of opportunities available to the worker, by raising access to new job offers and self-employment opportunities. ${ }^{8}$

In this case the probability of separation $q$ is endogenous, since the worker will stay with the current firm only if his outside option is lower than the wage he receives

\footnotetext{
${ }^{8}$ An alternative way is to assume that the arrival rate of job offers increases with training, for example because workers are more able to individuate adequate job opportunities. If we denote with $\lambda(s)$ the arrival rate of job offers and with $\varepsilon$ the shock hitting the worker's outside option, which has a distribution function $G(\varepsilon)$ and mean zero, then the expected value of the worker outside option is $\lambda(s) v(s)$ and the worker will leave when $\lambda(s) v(s)>w(s)$. The probability of quitting is $q=G[\lambda(s) v(s)-w(s)]$, from which $\frac{\partial q}{\partial s}=g\left(\lambda(s) v^{\prime}(s)-w^{\prime}(s)+\lambda^{\prime}(s) v(s)\right)$, which may result either positive or negative.
} 
in the current firm, which, as above, we assume to be the outcome of Nash bargaining. Formally the worker will remain with the firm when $v(s)+\varepsilon<v(s)+\beta[y(s)-$ $v(s)]$, which occurs with probability $\operatorname{Prob}\{\varepsilon<\beta[y(s)-v(s)]\}=\operatorname{Prob}\{\varepsilon<\beta[z(s)]\}$. The probability $q$ of leaving the firm is:

$$
q=1-\int_{-k(s)}^{z(s)} \frac{1}{2 k(s)} d \varepsilon=1-\frac{\beta[y(s)-v(s)]+k(s)}{2 k(s)}=\frac{k(s)-\beta[y(s)-v(s)]}{2 k(s)}(12)
$$

This probability can both increase or decrease with training. In the former case, the marginal benefits of training decline, with negative effects on the investment, while in the latter case they increase, with positive effects. In fact:

$$
\frac{\partial q}{\partial s}=\frac{\left\{k^{\prime}(s)-\beta\left[y^{\prime}(s)-v^{\prime}(s)\right]\right\} 2 k(s)+\{k(s)-\beta[y(s)-v(s)]\} 2 k^{\prime}(s)}{[2 k(s)]^{2}}
$$

If $k^{\prime}(s)=0,(13)$ becomes $\frac{\partial q}{\partial s}=\frac{-\beta\left[y^{\prime}(s)-v^{\prime}(s)\right]}{k(s)}$ and, since with wage compression $\left[y^{\prime}(s)-v^{\prime}(s)\right]>0$, the probability of quitting falls when training increases, with positive effects on training investment. However, this is not the case when $k^{\prime}(s)$ is positive, since training now increases the variability of the worker's outside option.

\section{The under - provision of training: empirical evidence}

The empirical literature on training suffers of measurement problems that hinder the achievement of ultimate conclusions. Training incidence and duration is usually measured using data drawn from household and employer surveys and from administrative data of single firms. These data contain self-reported training measures, which are affected by measurement errors because respondents may not exactly remember all their relevant training experiences, especially when the span of time between the training spell and the interview is long. Moreover, workers and firms may have different perceptions of training investments. As argued by Black and Lynch (1998) "..a supervisor who is assigned to work side-by-side with a new employee may view the time she spends with a new hire as training, whereas the employee views the fact that the supervisor is always hanging around as monitoring, not training". Barron et al. (1997) using data from a matched employer-employee survey, find that the correlation between worker and establishment measures are lower than 0.5 and that establishments report on average 25 percent more hours of training than workers do.

These problems and the fact that informal training is rarely recorded in any survey makes it difficult to test human capital theory of training. As far as the under provision of training is concerned, an additional complication is that training costs and returns - on which efficiency evaluations are based - are very difficult to measure. On the one hand, individual productivity is hardly ever measured and the wage, which should approximate productivity, varies with many other factors, including labor market competition. On the other hand, respondents to surveys are unlikely to know the opportunity cost of training and when training is financed by the firm and 
the respondents are workers, it is also difficult to assess the direct money cost of training.

Leaving aside these problems, a number of attempts has been made to evaluate the extent of under-provision, mainly based on training returns. According to some authors, the under-investment argument finds support in the combination of high private rates of return to training and low training incidence. Returns to training have usually been evaluated considering the effect of training on wages. Studies by Booth and Bryan (2007), Frazis and Loewenstein (1999), Arulampalam, Booth and Elias (1997), Mincer (1996), Blanchflower and Lynch (1994), suggest that private rates of return to training are considerably higher than the real rate of return of corporate bonds - 4 percent - and to schooling - about 5-10 percent (Bishop, 1994). Frazis and Lowenstein find that 40 hours of training increase the wages of persons with low levels of tenure and experience by 8 percent, as much as a single year of education. Carneiro and Heckman (2003) report that the return to private sector training in the US ranges between 16 and 26 percent. Evidence that the private returns to training are disproportionately high relative to other investments with similar risk suggests that there is some market failure, which prevents individuals from implementing their privately optimal plans. According to Lengermann (1996) since workers generally do not experience reductions in wage rates or hours worked while they received company training, their private rate of return to training tends to be infinite. This might explain the large numbers of American, Canadian, Dutch and Swedish workers reporting that they are unable to get all the training they would like (Loewenstein and Spletzer, 1999).

However, these estimates may be over-stated due to difficulties in controlling for self-selection of individuals to treatment. Some recent studies, which use more adequate instruments to control for selectivity, find lower returns. For example, training returns not significantly different from zero are found by Leuven and Oosterbeek (2002), who estimate the wage returns to work-related training by restricting the group of untreated individuals to those who were willing to receive training in the Netherlands, but did not do so due to some random event. Nevertheless, these results are based on a small sample and only thanks to new research going in the same direction we would be able to reach any general conclusion.

An additional problem of evaluations based on wages is that wage returns depend on the labour market structure. If firms have monopsonistic power, we may observe low wage returns even if training substantially increases productivity. Due to the lack of data on productivity, studies analysing the impact of training on productivity are fewer compared to studies focusing on wage effects. These studies find mixed results: on the one hand Zwick (2005) for Germany, Brunello (2004) and Conti $(2005)^{9}$ for Italy and Dearden et al. (2006) for UK, find a positive effect of training on productivity, while on the other hand, Black and Lynch (2001), using US data, do

\footnotetext{
${ }^{9}$ Conti (2005), using a variety of panel data techniques, shows that training has a positive and significant effect on productivity, robust to several estimation strategies, while the effect on wages is much less robust, and smaller in size.
} 
not find any effect.

However, even in case of high returns, studies missing data on training costs cannot reach definite conclusions on market failures. In fact, assuming that the marginal returns to training decrease with the stock invested, high observed returns are consistent both with the presence of market failures, which keep individuals and firms from investing efficiently, and with high marginal costs of training. While the former explanation supports under-provision, the latter explanation is perfectly in line with efficient provision. To reach ultimate conclusions it is necessary to have information on both benefits and costs. Recently, some studies, going in this direction, have tried to evaluate the employer's internal rate of return on investments in training (see Bartel, 2000, for a review). However, these investigations are mainly company case studies and their results can hardly be generalized. An exception is represented by a study conducted by Almeida and Carneiro (2006), using data from a sample of Portuguese firms. They estimate a joint rate of return for the employer and the employee of $10 \%$, which, however, varies considerably depending on the assumption made on depreciation rates. ${ }^{10}$

According to another line of investigation, instead of trying to directly evaluate whether the realized investments are efficient, important information can be obtained by looking for evidence suggesting market failures. While there is little if any evidence in support of under-provision because of liquidity constraints (see Messer and Wolter, $2009^{11}$ ), there is substantial evidence that the costs of training are financed by the employer, which can be read as an indicator of monopsony power (Barron, Berger and Black, 1999; Booth and Bryan, 2007; Loewenstein and Spletzer, 1998; Stevens, 1999). The willingness of firms to bear training costs could be due, however, to the firm - specific nature of the investment rather than to market power. The available empirical evidence suggests that skills provided by (formal) on-the-job training are seldom purely firm-specific (Neal 1995; Stevens 1994, 1999; Loewenstein and Spletzer, 1999), which points again to labor market imperfections. As documented by Bishop (1997), a growing number of firms are training their workers in completely general skills such as mathematics, reading, writing, problem solving and interpersonal skills. Similarly, OECD (2003a) reports that courses occurring outside the workplace impart essentially general skills.

The fact that firms pay for general training is also supported by the empirical literature investigating the influence of labour market institutions, such as the presence of unions and minimum wages, on training provision. The insignificant or positive effect of minimum wages on training provision found by a number of empirical works (Lazear and Miller, 1981; Acemoglu and Pischke, 2003; Arulampalam, Booth and Bryan, 2004; Grossberg and Sicilian, 1999) is not consistent with the beckerian approach while is consistent with models predicting that firms pay for general

\footnotetext{
${ }^{10}$ We are not aware of any study trying to evaluate the external effects of training.

${ }^{11}$ These authors analyse through a randomized experiment the effect of vouchers for adult learning. They show that the voucher had a significant effect on training participation, especially for individuals with low educational attainement.
} 
training. Similarly, the positive effect of unions on training emerging from a large number of analysis might be interpreted in relation to the role of unions in reducing turnover rates and in internalizing poaching externalities (Booth, 1991; Greenhalgh and Mavrotas, 1994; Lynch, 1992; Green, 1993; Kennedy at al. 1994; Arulampalam and Booth, 1998; Green, Machin and Wilkinson 1999, Booth, Francesconi and Zoega, 2003).

This empirical evidence, supporting the assumption of imperfectly competitive labor markets, confirms an under provision problem. However, there are two main objections to this line of reasoning. Firstly, the fact that firms formally pay for training does not imply that workers do not bear the cost through lower wages (as show before with $\beta=1$ investments are efficient). Secondly, a part from influencing productivity and wages, training might reduce separation rates. in this case both firms and workers will be induced to invest more and, even with imperfectly competitive labor markets, an efficient solution cannot be excluded.

As far as the first objection is concerned, when workers invest, we should observe a positive relationship between wage premia and training. Several papers investigate the relationship between training and wage compression and do not support this claim (Brunello, 2004; Ericson, 2004; Almeida-Santos and Mumford, 2005). For example, Bassanini and Brunello (2008) using data from the European Community Household Panel and measuring the training wage premium - for different subgroups of the employed population - as the differential between the median wage growth of trained and untrained employees, find a negative and statistically significant relationship between general training and the training wage premium.

According to these results, while workers may finance part of the investment in their general human capital, it is difficult to argue that they represent the unique investing subject: evidence does not seem to favor a return to Becker's theory. Nevertheless, even with imperfectly competitive labor markets efficiency cannot be ruled out if training reduces turnover. The relatively few papers that consider this issue and some new evidence on OECD countries will be discussed in the next section.

\section{Training and turnover}

The impact of training on turnover rates has received little attention in the economic literature. This is surprising both because turnover represents an important component of labor market outcomes and because, with imperfect labour markets, understanding the impact of training on turnover gives important insights for the evaluatation of whether there is an under-investment problem.

The few papers that address this issue are especially based on US data and obtain on the whole ambiguous results. Lynch (1991), using US data on young workers (National Longitudinal Survey of Youth), finds that while on the job training (more firm specific) reduces the probability of job separations, workers participating in offthe-job training (more general) are more likely to leave their current employer. Veum (1997) using the some source of data, concludes that trainees are equally likely to 
quit than non-trainees. Similar results are obtained by Krueger and Rouse (1998) focusing on personnel files from two large U.S. companies. In contrast, Parent (1999), using data from the NLSY, shows that on the job training decreases the probability of job separations ${ }^{12}$.

We investigate the empirical relationship between general training and turnover using ECHP data and focusing on voluntary quits. The ECHP dataset includes two interesting questions on turnover behaviour, which can be used to study whether (voluntary) turnover is affected by employer-provided training: first, workers are asked to indicate the year when they stopped working in their previous job. Second, they are asked to indicate the reason of separation. If we focus on individuals who were trained by the employer between year $t-1$ and year $t$ and compute the percentage of those who quitted between year $t+1$ and year $t+2$ - conditional on staying in the job in year $t$ - we find that the percentage of workers who leave for a better job is on average 6.94 percent in the sample of 11 European countries with available data ${ }^{13}$. This percentage increases to 9.88 percent when we add voluntary turnover due to non economic reasons - such as childbearing, moving, marriage and else. Therefore, a European employer who is considering training a worker can expect - based on this data, that 7 to 10 trained workers out of 100 quit between one and two years after training.

Does turnover decline among trained employees? We investigate this question by selecting the individuals who had received employer provided general training from January in the year $t-2$ to $t$, the time of the survey, and by asking whether they have quitted their last job in the year $t+1$, conditional of no turnover in year $t$. General training includes off the job training in vocational schools and systems providing both work experience and complementary instruction elsewhere. We choose to focus on turnover one year after the survey rather than in the same year to avoid the risk of having separations taking place before the training event, and to reduce endogeneity issues. The empirical model is

$$
q_{i t}=\alpha+\beta X_{i t}+\gamma \tau_{i, t-1}+f_{i}+\varepsilon_{i t}
$$

where $q$ is turnover - a dummy equal to 1 in the event of turnover and to 0 otherwise; $X$ is a vector of time varying controls, $\tau$ is the training dummy, $c$ is an individual fixed effect and $\varepsilon$ is a random error orthogonal to training. If more able individuals are less likely to quit and more likely to receive training, failure to account for unmeasured individual fixed effects could seriously bias downwards our estimates. To take this into account, we estimate a linear probability model using fixed effects. The vector $X$ includes age, age squared, year dummies and five dummies representing the time varying degree of job satisfaction. Table 1 reports the estimates separately for turnover to a better job - column 1 in the table - and for any voluntary turnover -

\footnotetext{
${ }^{12}$ Brunello and De Paola (2008), using a sample of Italian firms, show that training is lower in provinces with higher labor market density, implying that poaching may negatively affect training.

${ }^{13}$ These countries are Denmark, Belgium, France, the UK, Ireland, Italy, Greece, Spain, Portugal, Austria and Finland.
} 
column 2. In these estimates, we consider the period 1996-2000 and restrict our attention to individuals aged 25 to 54. As expected, our estimates show that turnover declines with age and with the index of job satisfaction. Conditional on these factors, the relationship between training and turnover is negative, small and not statistically different from zero.

Table 1: Estimates of the probability of separation in year $t+1$ as a function of employer provided training in years $t-2$ to $t$. Linear probability model. Fixed effects. 1996-2000

\begin{tabular}{lcc} 
& $\begin{array}{c}\text { Quitted because } \\
\text { of a better job }\end{array}$ & $\begin{array}{c}\text { Quitted for } \\
\text { different reasons }\end{array}$ \\
\hline Trained by employer between & -0.003 & -0.005 \\
year t-2 and $\mathrm{t}$ & $(0.005)$ & $(0.003)$ \\
Age & $-0.032^{* * *}$ & $-0.022^{* * *}$ \\
& $(0.005)$ & $(0.004)$ \\
Age squared & $0.0003 * * *$ & $0.0002 * * *$ \\
& $(0.000)$ & $(0.000)$ \\
Job satisfaction at time t: level 2 & -0.012 & -0.004 \\
& $(0.012)$ & $(0.007)$ \\
Job satisfaction at time t: level 3 & -0.014 & -0.009 \\
& $(0.010)$ & $(0.008)$ \\
Job satisfaction at time t: level 4 & $-0.024 * * *$ & $-0.020 * * *$ \\
& $(0.011)$ & $(0.007)$ \\
Job satisfaction at time t: level 5 & $-0.044 * * *$ & $-0.036 * * *$ \\
& $(0.010)$ & $(0.008)$ \\
Job satisfaction at time t: level 6 & $-0.052^{* * *}$ & $-0.038^{* * *}$ \\
& $(0.010)$ & $(0.009)$ \\
\hline Number of observations & 52014 & 52014 \\
\hline
\end{tabular}

Notes: standard errors in parentheses with $* p<0.10$, ** $p<0.05, * * * p<0.01$. Each regression includes a constant and year dummies.

\section{Concluding remarks}

Training and education have become standard keywords in most policy proposals dealing with unemployment, competitiveness and growth. These proposals almost unanimously suggest that proper policies should be designed to foster more education and more training. Are these proposals well justified on economic grounds?

Although there is a large consensus in the economic literature on the importance of training, there is less agreement on whether the observed levels of investment in training are efficient. This also because, even if there are many theoretical reason for under-investment, it is very hard to find empirical evidence. 
This paper has reviewed both the theoretical underpinnings and the empirical evidence in support of under-provision of training. It has been shown that it is difficult to find direct evidence on under-provision. The existing empirical evidence on training costs and returns does not reach any ultimate conclusion, both because of measurement problem, lack of data and estimation issues.

On the other hand, the indirect evidence emerging from a number of papers showing that firms pay for general training, may not be particularly relevant if training reduces turnover. In case of imperfectly competitive labor markets, the supply of training by firms is higher than in perfect competition, because wage compression increases profits, but the demand for training by employees is lower than in perfect competition, because the wage gain from training is lower. As argued by Stevens, 2001, the fall in demand outweighs the increase in supply, because the employer gains only if the employee stays on. Therefore, training is lower than in the first best allocation even in the absence of liquidity constraints.

In the theoretical part of the paper, we have shown that results may change if training reduces turnover rates. We have investigated this issue using the ECHP dataset covering a large number of European countries, without reaching conclusive results. Our estimates point to a negative but not statistically significant relationship between training and turnover. As the theory suggests, a negative relationship can allow private agents to attain the first best or even to over-invest in the provision of general training.

We conclude that the empirical evidence on training under-investment is not sufficient to justify on efficiency grounds training policies widespread in many OECD countries. More needs to be done in order to understand whether market forces are able to generate efficient levels of investments and in case of a negative answer to understand how large is under-provision and what generates it. The identification of market failures determining training under-provision and the understanding of those factors producing large differences in investments realized by different groups of individuals is crucial for the design of effective policies. In addition, since public failures are also well-known, an adequate evaluation of the under-investment costs and the intervention costs represents a crucial step before prescribing any policy. Policies diffused in many countries do not seem to be based on this kind of knowledge and the risk of cosmetic schemes, considerable deadweight losses and substitution effects seems to be particularly high ${ }^{14}$.

\section{References}

Acemoglu, D. (1997). Training and innovation in an imperfect labor market. Review of Economic Studies, 64, 445-464.

Acemoglu, D. \& Pischke, J. (1998). Why do firms train? Theory and evidence. Quarterly Journal of Economics, 113, 79-119.

Acemoglu, D. \& Pischke, J. (1999a). Beyond Becker: Training in imperfect labor market. Economic Journal, 109 (February), 112-142.

\footnotetext{
${ }^{14}$ See Brunello et al. (2007) for a detailed discussion of policy issues.
} 
Acemoglu, D. \& Pischke, J. (1999b). The structure of wages and investment in general training. Journal of Political Economy, 107, 539-572.

Acemoglu, D. \& Pischke J. (2003). Minimum wage and on-the-job training. Research in Labor Economics, 22, 159-202.

Almeida R. \& Carneiro P. (2006). The Return to the firm investment in human capital. IZA Discussion Papers 1937.

Almeida-Santos, F. \& Mumford, K. (2005). Employee training, wage compression and workplace performance in Britain. Manchester School, University of Manchester, 73(3), 321-342.

Arulampalam, W. \& Booth A. (1998). Labour market flexibility and skills acquisition: Is there a tradeoff?. British Journal of Industrial Relations, 36 (4), 521-536.

Arulampalam, W. \& Booth A. (2001). Learning and earning: Do multiple training events pay? A decade of evidence from a cohort of young British men. Economica, 68 (271), 379-400.

Arulampalam, W., Booth A. \& Bryan M. (2004). Training and the new minimum wage. Economic Journal, 114(494), C87-C94.

Arulampalam, W., Booth A. \& Elias, P. (1997). Work-related training and earnings growth for young men in Britain. In S. Polachek (Ed.) Research in Labor Economics, 16. Greenwich, Conn. and London: JAI Press.

Barron, J. M., Berger, M. \& Black D. (1997). On-the-job training. W.E Upjohn Institute for Employment Research.

Barron, J. M., Berger, M. \& Black, D. (1999). Do workers pay for on-the-job training?. Journal of Human Resources, 34(2), 236-252.

Bartel, A. (2000). Measuring the employer's return on investments in training: Evidence from the literature. Industrial Relations, 39(3), 502-524.

Bassanini, A. \& Brunello G. (2008). Is training more frequent when wage compression is higher? Evidence from the ECHP. Labour Economics, 15(2), 272-290.

Becker, G. (1962). Investment in human capital: a theoretical analysis. Journal of Political Economy, $70,9-49$.

Becker, G. (1964). Human capital. Chicago: The University of Chicago Press.

Bishop, J. (1994). The impact of previous training on pro-ductivity and wages. In L. Lynch (Eds.) Training and the Private Sector: International Comparisons. Chicago: University of Chicago Press.

Bishop, J. (1997). What we know about employer-provided training: A review of the literature. In S. Polachek \& W. Solomon (Eds.) Research in Labor Economics. London: JAI Press.

Black, S. \& Lynch, L. (1998). Beyond the incidence of employer-provided training. Industrial and Labor Relations Review, 52(1), 64-81.

Black, S. \& Lynch, L. (2001). How to compete: The impact of workplace practices and information technology on productivity. The Review of Economics and Statistics, 83, 434-445.

Blanchflower, D. \& Lynch, L. (1994). Training at work: A comparison of U.S. and British youths. In Lynch, L. (Ed.) Training and the private sector: International comparisons. National Bureau of Economic Research, Comparative Labor Markets Series. Chicago and London: University of Chicago Press.

Blau, F. \& Kahn, L. (1983). Job search and unionized employment. Economic Inquiry, 21 (3), 412-30.

Booth, A. (1991). Job-related formal training: Who receives it and what is it worth?. Oxford Bulletin of Economics and Statistics, 53, 281-294.

Booth, A. \& Chatterji M. (1998). Unions and efficient training. The Economic Journal, 108 (447), 328-343.

Booth, A. \& Bryan M. (2007). Who pays for general training in private sector Britain. Research in Labor Economics, 26, 83-121.

Booth, A., Francesconi, M., \& Zoega G. (2003). Unions, work-related training and wages: Evidence for British men. Industrial and Labor Relations Review, 57(1), 68-91.

Booth A. \& Zoega G. (2000). Why do firms invest in general training? 'Good' firms and 'bad' firms as a source of monopsony power. University of Essex, Institute for Labour Research Working Papers No. 058 . 
Brunello, G. (2004). On the complementarity between education and training in Europe. In D. Checchi \& C. Lucifora, (Eds.) Education, training and labour market outcomes in Europe. Basingstoke, U.K.: Palgrave, McMillan.

Brunello, G. \& De Paola, M. (2008). Training and economic density: Some evidence from Italian provinces. Labour Economics, 15(1), 118-140.

Brunello G. , Garibaldi P. \& Wasmer E. (2007). Education and training in Europe. Oxford: Oxford Economic Press.

Carneiro P. \& Heckman, J. (2003). Human capital policy, in inequality in America: What role for human capital policies. In J. Heckman \& A. Krueger (Eds.). Massachusetts: MIT Press.

Conti G. (2005). Training, productivity and wages in Italy. Labour Economics, 12(4), 557-576.

De la Fuente A. \& Ciccone, A. (2002). Human capital in a global and knowledge-based economy. European Commission. Employment and Social Affairs.

De Paola M. \& Scoppa V. (2003). Complementariet tra istruzione e investimenti in training delle imprese: alcune interpretazioni teoriche. Rivista di Politica Economica, 92 (9-10), 97-127.

Dearden, L., Reed H. \& Van Reenen J. (2006). The Impact of training on productivity and wages: Evidence from British panel data. Oxford Bulletin of Economics and Statistics, 68(4), 397-421.

Ericson T. (2004). The Effects of wage compression on training: Swedish empirical evidence. Institute for labour market policy evaluation Working Paper No. 2004:15.

Fella, G. (2005). Termination restrictions and investment in general training. European Economic Review, 49(6), 1479-1499.

Frazis, H., \& Loewenstein M. A. (1999). Reexamining the returns to training: Functional form, magnitude, and interpretation. United States Bureau of Labor Statistics, Office of Employment Research and Program Development Working Paper No. 325.

Freeman, R. \& Medoff, J. (1984). What do unions do?. New York: Basic Books.

Green, F. (1993). The determinants of training of male and female employees in Britain. Oxford Bulletin of Economics and Statistics, 55(1), 103-22.

Green, F., Machin, S. \& Wilkinson D. (1999). Trade unions and training practices in British workplaces. Industrial and Labor Relations Review, 52(2), 179-195.

Greenhalgh, C. \& Mavrotas G. (1994). The role of career aspirations and financial constraints in individual access to vocational training. Oxford Economic Papers, 46, 579-604.

Grossberg A. \& Sicilian P. (1999). Minimum wages, training and wage growth. Southern Economic Journal, 65, 539-556.

Hashimoto, M. (1981). Firm-specific human capital as a shared investment. American Economic Review, 71, 475-482.

Jansen, M. (1998). Tenure, training and unemployment. Universitat Pompeu Fabra, mimeo.

Kahn, C., \& Huberman, G. (1988). Two-sided uncertainty and 'up-or-out' contracts. Journal of Labor Economics, 6, 423-44.

Katz, E. \& Zidermann, A. (1990). Investment in general training: The role of information and labour mobility. Economic Journal, 100, 1147-58.

Kennedy, S., Drago, R., Sloan, J. \& Wooden, M.(1994). The effect of trade unions on the Proand Humanities Research Council of Canada. Vision of Training: Australian Evidence. Journal of Industrial Relations, 32(4), 565-580.

Krueger, A. \& Rouse C. (1998). The Effect of workplace education on earnings, turnover, and job performance. Journal of Labor Economics, 16, 61-94.

Layard, R., Robinson, P. \& Steedman, H. (1995). Lifelong learning. CEP occasional paper No. 9.

Lazear, E. \& Miller F. (1981). Minimum wage versus minimum compensation. In Report of the minimum wage study commission 5. Washington, DC: U.S. Government Printing Office.

Lengermann, P. (1996). Training's impact on wages and hours worked: A comparison of the benefits and costs of training. Economics of Education Review, 6, 100-127.

Leuven, E. (2005). The economics of private-sector training. Journal of Economic Surveys, 19(1), 91-111.

Leuven, E. \& Oosterbeek H. (2008). An alternative approach to estimate the wage returns to privatesector training. Journal of Applied Econometrics, 23, 423-434.

Loewenstein M. A., \& Spletzer J. (1998). Dividing the costs and returns to general training. Journal of Labor Economics, 16(1), 142-171. 
Lowenstein, M., \& Spletzer J. (1999). General and specific training: Evidence and implications. Journal of Human Resources, 34(4), 710-733.

Lynch, L. M. (1991). The role of off-the job vs. on-the-job training for the mobility of young women workers. American Economic Review, 81, 151-156.

Lynch, L. (1992). Private sector training and the earnings of young workers. American Economic Review, 82, 299-312.

Malcomson, J., Maw, J., \& McCormick B. (2002). General training by firms, apprentice contracts, and public policy. European Economic Review, 47(1), 197-227.

MacLeod, B. \& Malcomson, J. (1993). Specific investments and wage profiles in labour markets. European Economic Review, 37, 343-354.

Messer D. \& Wolter S. (2009). Money matters-Evidence from a large-scale randomized field experiment with vouchers for adult training. CESifo Discussion Paper.

Mincer J. (1996). Training: Costs, returns, and wage profiles, the economics of training, theory and measurement. In O. Ashenfelter \& R. LaLonde (Eds) Elgar reference collection, International Library of Critical Writings in Economics, 65. Cheltenham, U.K.

Neal, D. (1995). Industry-specific human capital: Evidence from displaced workers. Journal of Labor Economics, 13(4), 653-677.

OECD (1999). Employment outlook. Paris.

OECD (2001). The economics and finance of lifelong learning. Paris.

OECD (2003a). Upgrading workers' skills and competencies. In Employment Outlook. Paris.

OECD (2003b). Descriptions and evaluations of recent experience with mechanisms for co-financing lifelong learning: Reports prepared by national authorities and members of the ELAP network, prepared for the Second International Seminar: Mechanisms for the co-finance of lifelong learning, London, 27-29 November. Paris.

Ok W. \& Tergeist, P. (2003). Improving workers' skills: Analytical evidence and the role of the social partners. OECD Social, Employment and Migration Working Papers.

Parent, D. (1999). Wages and mobility: The impact of employer-provided training. Journal of Labor Economics, 17, 298-317.

Prendergast, C. (1993). The role of promotion in inducing specific human capital acquisition. Quarterly Journal of Economics, 108, 523-34.

Ryan, P. (1994). Training quality and trainee exploitation. In R. Layard, K. Mayhew \& G. Owen (Eds.) Britain's Training Deficit. Aldershot: Avebury.

Stevens, M. (1994). A Theoretical model of on-the-job training with imperfect competition. Oxford Economic Papers, 46(4), 537-562.

Stevens, M. (1996). Transferable training and poaching externalities. In A.L. Booth \& D.J. Snower (Eds.) Acquiring skills: Market failures, their symptoms and policy responses. Cambridge, UK: Cambridge University Press.

Stevens, M. (1999). Human capital Theory and UK vocational training policy. Oxford Review of Economic Policy, 15(1), 16-32.

Stevens, M. (2001). Should firms be required to pay for vocational training?. Economic Journal, 111, 485-505.

Williamson, O. (1975). Markets and hierarchies. New York: The Free Press.

Veum, J. R. (1997). Training and job mobility among young workers in the United States. Journal of Population Economics, 10, 219-233.

Zwick, T. (2005). Continuing vocational training forms and establishment productivity in Germany. German Economic Review, 6(2), 155-184. 